\title{
Innovations and Socio-Economic Development: Problems of the Natural Resources Intensive Use Regions
}

\author{
Pogodaeva Taisia V. \\ Zhaparova Darya V.
}

Tyumen State University; Tyumen, Russia

Email: taisyapogodaeva@gmail.com; daria_90@mail.ru

Rudenko Dmitry Y.

Tyumen State University; Tyumen State Academy of World Economy, Management and Law; Tyumen, Russia

Email:drudenko@inbox.ru

Skripnuk Djamilia F.

St. Petersburg State Polytechnical University; Russia

Email: djamilyas@mail.ru

\section{Doi:10.5901/mjss.2015.v6n1p129}

\section{Abstract}

In the context of the economic growth slowdown and the continued deepening of the Russian regions' social and economic differentiation there is the problem of spatial development. The study of innovation factors' impact on the social and economic development attains a particular interest in this context. In the article the econometric model of the innovation factors' impact on the social and economic development of the Russian regions is constructed. The results of the analysis indicate the imbalance of the regions' innovative development, which is determined by the absence of significant impact of indicators that characterize the process of instilling innovations. The innovative development analysis of the Tyumen region as a natural resources intensive use region indicates the relative lag behind not only the leading regions, but also behind the mean values. The necessity of institutional changes in order to stimulate the business' innovative development and in the first place the oil and gas sector's innovative development is based. Arctic projects have significant potential in this direction.

Keywords: innovative development, social and economic development, region of the natural resources intensive use, oil and gas sector, institutional environment, formation of the circumpolar area innovative system.

\section{Introduction}

In the context of an economic growth slowdown and the continued deepening of the Russian regions' social and economic differentiation there is the problem of spatial development factors' identification and implementation on the agenda. «A new economic geography» singles out two groups of factors, which affect territories' development in different combinations and in a different degree, - the factors of "the first nature" and "the second nature" (Krugman, 1993). The peculiarity of Russian regional development is a leading role of factors of "the first nature", first of all, of the mineral resources provision and at the same time the potential of factors of "the second nature" is not only unused, but in the majority of cases acts as a barrier of regional development (Zubarevich, 2011). One of these barriers is openness and inequality of the regions' innovative development against the background of actual lack of the innovations' inter-regional transmission mechanisms (Didenko N., Skripnuk D., 2014). The world development experience shows that innovative development stimulation lets overcome historically established specialization of the regions and form the firm trends of social and economic development. The crucial direction of the research is an evaluation of the innovative factors influence on the Russian regions social and economic development.

A number of scientists has been studying the influence of innovative factors on the social and economic development of the regions in the Russian science. L.M. Gochberg and I.A. Kuznetsova conclude that the low innovative activity is associated with the fact that economic agents are not receptive to innovations (Goxberg L., Kuznetsova I., 
2004, Goxberg L., 2012). K.K. Kozlov, D.G. Sokolov and K.V. Yudaeva emphasize the low culture of innovative management and the low quality of corporate governance in their study (Kuznetsov S.A., Kravchenko N.A., Markov V.D., Yusupova A.T., 2005). I.G. Dezhina and B.G. Saltykov pay attention to the fact that innovative infrastructure and support system for small innovative businesses are not developed (Dezhina I.G., Saltykov B.G., 2005). E.G. Yasin and A.E. Yakovlev are considering the low level of innovative factors influence on the economic development of the regions in terms of institutional structure (Yasin E.G., Akendinova N.V., Yakobson L.I., Yakovlev A.E., 2013). In the regions with raw specialization that are focused on the extraction of natural resource rents, the most archaic and undeveloped institutions have been formed, which lead to the lack of actors' motivation for innovations, to the deficit of institutional intermediaries, and to the weak institutions of development.

\section{Methodology}

Using the abstract-logical method and a set of methods of economic, statistical and econometric analysis in the present work, we examined the innovative development of Russian regions, defined its differentiation, and highlighted the features of the natural resources intensive use regions. Regression analysis provides the broad opportunities to identify the impact of factors on changing in the result variable. Therefore, it is appropriate to use for estimate the impact of innovation factors on socio-economic development of Russian regions. Regression analysis shows, firstly, the adequacy of the model used, and secondly, regression analysis calculates the values of the coefficients, that is, determines the strength of the arguments (indicators of innovation development) on the function result variable (GRP per capita).

The econometric evaluation of correlation of region's innovative development and GRP per capita has been held (Regions of Russian Federation, 2013). Three regression models were built: pooled regression, regression with determined individual effects (FE) and regression with random individual effects (RE). The received evaluations were tested on the econometric correctness, which let us choose the model with the better qualitative characteristics.

Within the framework of the research, the comparison between the regression model with the constant effects and the pooled regression was held by means of the Wald test, the comparison between the regression model with random individual effects (RE) and the pooled regression was held by means of the Breusch-Pagan test, and the regression model with random individual effects (RE) was compared with the regression model with determined individual effects (FE) by means of the Hausman test. The results of the carried tests let us conclude that the model with determined individual effects (FE) is the most acceptable in our case.

\section{Results}

The regression model with determined individual effects (FE), the regression "within" has shown that internal costs on the scientific researches and elaboration, costs on the technological innovations and number of the created advanced manufacturing sciences have the greatest influence on GRP per capita. The most significant variables are also: volume of the innovative goods, operations and services; quantity of researchers with scientific degrees; number of postgraduates and doctoral candidates; coefficient of inventive activity. All the regressors are timed-variables, so we were managed to evaluate all of the coefficients, and a comparison of standard mistakes of the pooled regression and the regression "within" points that the received evaluations are not less effective than evaluations of the pooled regression.

The results of the carried econometric analysis are shown in the table 1. 
Table 1. The results of evaluation of the correlation between region's innovative development and GRP per capita

\begin{tabular}{|c|c|c|c|}
\hline \multirow[t]{2}{*}{ Regressors } & \multicolumn{3}{|c|}{ Dependent variable - GDP per capita } \\
\hline & $\begin{array}{l}\text { Linear regression } \\
\text { model }\end{array}$ & $\begin{array}{l}\text { Model «within» with } \\
\text { the fixed effects }\end{array}$ & $\begin{array}{l}\text { Model «within» with the } \\
\text { random effects }\end{array}$ \\
\hline Internal costs on the scientific researches and & $43.014^{\star \star \star}$ & $20.025^{*}$ & $21.132^{\star \star}$ \\
\hline development in \% to GRP & $(7.453)$ & $(11.661)$ & $(7.720)$ \\
\hline Costs on the technological innovations in $\%$ to & & $2.12^{\star *}$ & $2.207^{* *}$ \\
\hline GRP & & $(0.878)$ & $(0.874)$ \\
\hline Volume of the innovative goods, operations and & $0.816^{\star \star \star}$ & $0.258^{* \star}$ & $0.487^{\star \star *}$ \\
\hline services in $\%$ to GRP & $(0.105)$ & $(0.124)$ & $(0.098)$ \\
\hline Staff quantity that is busy with scientific & $0.07^{\star \star \star}$ & & \\
\hline researches and elaborations per 10000 EAP & $(0.018)$ & & \\
\hline Quantity of the researchers with scientific degrees & & $0.255^{\star *}$ & $0.259 * * *$ \\
\hline per 10000 EAP & & $(0.099)$ & $(0.07)$ \\
\hline Coefficient of inventive activity & $\begin{array}{c}-0.111^{\star * \star} \\
(0.042)\end{array}$ & & \\
\hline $\begin{array}{l}\text { Number of the created advanced manufacturing } \\
\text { sciences per } 10000 \text { EAP }\end{array}$ & & $\begin{array}{c}6.507 * \star * \\
(1.634)\end{array}$ & $\begin{array}{c}7.150^{\star * \star} \\
(1.536)\end{array}$ \\
\hline $\begin{array}{l}\text { Number of the used advanced manufacturing } \\
\text { sciences per } 10000 \text { EAP }\end{array}$ & & & \\
\hline Ratios of the patent applications arrivals to the & & $0.134^{\star *}$ & $0.095^{\star}$ \\
\hline number of researchers & & $(0.064)$ & $(0.049)$ \\
\hline Innovative activity & & & \\
\hline Constant & $11.754^{\star \star *}$ & $12.746 * * \star$ & $11.973^{\star * *}$ \\
\hline & $(0.092)$ & $(0.254)$ & $(0.119)$ \\
\hline Number of observations & 240 & 240 & 240 \\
\hline Number of regions & 80 & 80 & 80 \\
\hline R-squared & 0.4938 & 0.3813 & 0.3287 \\
\hline F-statistic & 20.22 & 8.35 & $130.99(1)$ \\
\hline Probability (F-statistic) & 0.000 & 0.000 & 0.000 \\
\hline
\end{tabular}

Figures in parentheses are standard errors.

(1) - the interpretation of the model should not rely on the R-square, so as to regression, estimated by the method of GLS, it is no longer an adequate measure of the quality of the fit. The significance of the regression shows a high value of Wald statistic $=130.99$.

The results of the analysis testify the high degree influence of innovative on the social and economic level of region's development. An equation of the regression model with determined individual effects (FE) is given by (1):

$Y=20.025 X_{1}+2.12 X_{2}+0.255 X_{3}+6.507 X_{4}+0.134 X_{5}+12.746$

The following indices as internal costs on the scientific researches and elaboration in \% to GRP; number of the created advanced manufacturing sciences per 10000 EAP; costs on the technological innovations in \% to GRP; volume of the innovative goods, operations and services in \% to GRP; quantity of researchers with scientific degrees per 10000 EAP; ratios of the arrivals of patent applications to the number of researchers, which characterize the level of the innovative development of the region, have the greatest influence on GRP per capita.

The results of the research demonstrate that nowadays there is a misbalance of the regions' innovative development and it is displayed in the absence of the significant influence of the indices that characterize the process of innovations' implementation. In fact, the following situation occurs: financing of fundamental and applied researches is accounted for public funds, the making of models and commercialization of the innovative goods occurs abroad and then domestic business buys the finished technological solutions. It is connected to a large extent with rather low effectiveness of the innovative infrastructure work, "underestimation of the "soft" infrastructure importance (nets, interaction between the elements of the regional innovative infrastructure), and also with a prevailing role of government in creation of innovative infrastructure objects - both in a part of creation initiative and in a part of financing" (Barinova V.A., Maltsev A.A., Sorokin A.V., Eremin V.A., 2014). 
Presence of the essential differentiation into the level of the innovative development of Russian regions is stipulating the necessity to reveal the differences in innovative growth sources. The learning of the regions-leaders according to the level of the innovative development let us reveal "the growing-points" and evaluate a degree of the innovative component influence on the social and economic development. The econometric analysis of 20 regions taking the first 20 places in a rating of the innovative regions in 2013 let us get the following results (Table 2) (Ivanova O., Sorokina A., 2013).

Table 2. The regression model with the random effects of evaluation of the correlation between region's innovative development and GRP per capita according to 20 regions-leaders in a rating of the innovative regions

\begin{tabular}{|c|c|c|c|c|c|c|}
\hline & \begin{tabular}{|c|} 
Costs on the \\
technological \\
innovations in \% to \\
GRP \\
\end{tabular} & $\begin{array}{l}\text { Volume of the } \\
\text { innovative goods, } \\
\text { operations and } \\
\text { services in \% to GRP }\end{array}$ & $\begin{array}{l}\text { Quantity of the } \\
\text { researchers with } \\
\text { scientific degrees per } \\
10000 \text { EAP }\end{array}$ & $\begin{array}{l}\text { Coefficient of } \\
\text { inventive } \\
\text { activity }\end{array}$ & $\begin{array}{l}\text { Number of the used } \\
\text { advanced manufacturing } \\
\text { sciences per } 10000 \text { EAP }\end{array}$ & $\begin{array}{c}\text { Innovative } \\
\text { activity }\end{array}$ \\
\hline $\begin{array}{c}\text { GRP } \\
\text { per } \\
\text { capita }\end{array}$ & $\begin{array}{l}1.951^{*} \\
(1.054)\end{array}$ & $\begin{array}{c}0.575^{\star \star \star} \\
(0.139)\end{array}$ & $\begin{array}{c}0.191^{\star * *} \\
(0.047)\end{array}$ & $\begin{array}{c}0.142^{\star * *} \\
(0.042)\end{array}$ & $\begin{array}{l}0.05^{\star \star *} \\
(0.017)\end{array}$ & $\begin{array}{c}2.725^{\star * \star} \\
(0.739)\end{array}$ \\
\hline \multicolumn{7}{|c|}{$\begin{array}{l}\text { Constant }-11.365^{\star \star \star} \\
(0.178) \\
\text { Number of observations - } 60 \\
\text { Number of regions - } 20 \\
\text { R-squared }-0.375 \\
\text { Wald statistic }-120.45 \\
\text { Probability (F-statistic) }-0.0000\end{array}$} \\
\hline
\end{tabular}

The model "Within" with the random individual effects (RE) let us get the most appropriate evaluation of the regression. The equation of the regression of this model is given by (2):

$$
Y=1.951 X_{1}+0.575 X_{2}+0.191 X_{3}+0.142 X_{4}+0.05 X_{5}+2.725 X_{6}+11.365 \text { (2) }
$$

For the regions-leaders in a rating of the innovative development the quantity of the indices that characterize a degree of innovation development and have a significant influence $(\alpha=0,01)$ on GRP per capita has considerably risen. The level of innovative activity; volume of the innovative goods, operations and services in \% to GRP; quantity of researchers with scientific degrees per 10000 EAP; coefficient of inventive activity; and number of the used advanced manufacturing sciences per 10000 EAP were ranked among them.

The increasing of the innovative development level lets extend the channels of influence on GRP per capita that stimulates greater growth of innovative activity. Thus, the sustainable development of the region depends on its ability to organize a complete innovative cycle, which provides the systemacy of the processes of elements' development in space and time.

The received results testify a relative balance of the structure of the innovative growth's sources in the regionsleaders: the innovative process, the innovations proper and their practical implementation. However, from the position of a certain region the analysis testifies the uniform development of the innovative cycle's elements only in a range of regions-leaders. In majority of this group's regions the high values of ones indices are accompanied with the low values of the others. The result is a relatively smoothed evaluation that hides the presence of systemic problems of the innovative development. In accordance with the rating's data of innovative development of the subjects of Russian Federation, the only two regions from the group of leaders, particularly Moscow and Sverdlovsk Region, differ with the uniform development of the innovative index components (Ivanova O., Sorokina A., 2013, p.18). Besides, the low effectiveness of the interregional diffusion of innovations mechanisms acts as a significant restriction, there is a considerable research potential in a number of regions, but there are not enough opportunities of its practical application.

Nowadays, "the call" of the regional policy is the necessity of the innovative development and it is dictated by the global trends of world economy and a high importance of this sphere for region's social and economic development. Evidently, the achievement of the challenges is impossible without formation and development of the regional innovative systems that take into account the features of regions' development and lean on their competitive advantages. Though, the received results let us emphasize the problem of "openness", and frequently, of "isolation" of the regional innovative system. The mentioned problem is lying on the institutional plane, "bad" institutes are a barrier of the innovative development in the regions and at this conjuncture the stimulation of the innovative development is becoming 
transformed into the process of "agonizing implementation" of innovations to economics. The thorniest problem of the institutional environment quality is in the regions with a dominant raw-material orientation and dominance of the gas-andoil producing sectors into their structure. "The up-to-date situation" at the sphere of subsurface management in Russia is an illustration of where an imperfection of a system, both basic and complementary institutes, can lead and is leading to...Up to the present moment it wasn't managed to supply such a nature of adaptation and usage of mineral resources that would respect the interests of the meaningful part of society, but not only the interests of those ones in whose hands there're control packets of shares of the subsurface resources companies-users" (Kryukov V.A., 2009).

The principal Russian region with a dominant raw-material orientation and dominance of the oil-and-gas producing sector into their structure is Tyumen Region. In 2013316.4 millions tons of oil and condensate as well as 597.6 billions of gas $\mathrm{m}^{3}$ have been extracted in the region, that is relatively $60.5 \%$ and $87.4 \%$ from a total volume of nation's extraction (Eder L.V., Filimonov I.V., Provornaya I.V., Nemov V., 2014). Moreover, according to a plan of "The Tobolsk's Project" realization, the oil extraction can be brought up to 30 millions tons of oil per year only in the South of Tyumen Region. That exceeds the today's rate in two times.

In 2012, GRP of Tyumen Region was 4618.711 billion rubles (9\% GDP). The region takes the second place by this index giving the first place to Moscow. Thus, Tyumen Region is contributing in the social and economic development of Russia, but, according to researches, the innovative development of the region is at extremely insufficient level.

In accordance with the results of the innovative development's rating of the subjects of Russian Federation in 2014, Tyumen Region takes the $19^{\text {th }}$ place and relates to the second group of regions. The strong region's position is the social and economic conditions of innovative activity; by this criterion, Tyumen Region takes the $6^{\text {th }}$ place in a rating. The weaknesses are innovative activity (36 place) and quality of the innovative policy (32 place) (Rating $f$ innovative development of the Russian Federation, 2014).

Within the framework of analysis of innovative regional system formation and development, it is obligatory to carry out the appraisal of the innovative regional system present condition by means of the statistical indices system, on the basis of which the positions of Tyumen Region are identified relative to the regions-leaders and to the average values. According to the majority of indices the region is essentially backward the average Russian indices. The biggest lag is noted by the innovative activity index, staff quantity that is busy with scientific researches and developments and number of the created advanced manufacturing sciences. Such low positions are explained by the raw model of the regional economy and relatively low innovative activity of the oil-and-gas sector's companies in comparison with their contribution in GRP (table 3) (Regions of Russian Federation, 2013).

Table 3. Comparative analysis of the Tyumen region's innovative development level with the leading regions and regional average values of Russia, 2012

\begin{tabular}{|c|c|c|c|}
\hline Indices & \multicolumn{3}{|c|}{ Tyumen Region Average Value Region-leade } \\
\hline Innovative activity & 8.2 & 10.4 & 24.6 \\
\hline Internal costs on the scientific researches and development in \% to GRP & 0.19 & 0.85 & 5.3 \\
\hline Costs on the technological innovations in \% to GRP & 0.73 & 1.5 & 7.9 \\
\hline Volume of the innovative goods, operations and services in \% to GRP & 1.02 & 0.71 & 1.48 \\
\hline Staff quantity that is busy with scientific researches and elaborations per 10000 EAP & 3.56 & 5.22 & 34.46 \\
\hline Quantity of the researchers with scientific degrees per 10000 EAP & 0.47 & 0.81 & 6.82 \\
\hline Coefficient of inventive activity & 0.54 & 1.25 & 7.38 \\
\hline Number of the created advanced manufacturing sciences per 10000 EAP & 0.41 & 1.3 & 8.9 \\
\hline Number of the used advanced manufacturing sciences per 10000 EAP & 3.73 & 2.32 & 6.1 \\
\hline Ratios of the patent applications arrivals to the number of researchers & 0.39 & 0.79 & 4.27 \\
\hline
\end{tabular}

Number of the used advanced manufacturing sciences and volume of the innovative goods, operations and services in Tyumen Region are exceed the average Russian indices (fig.1). 


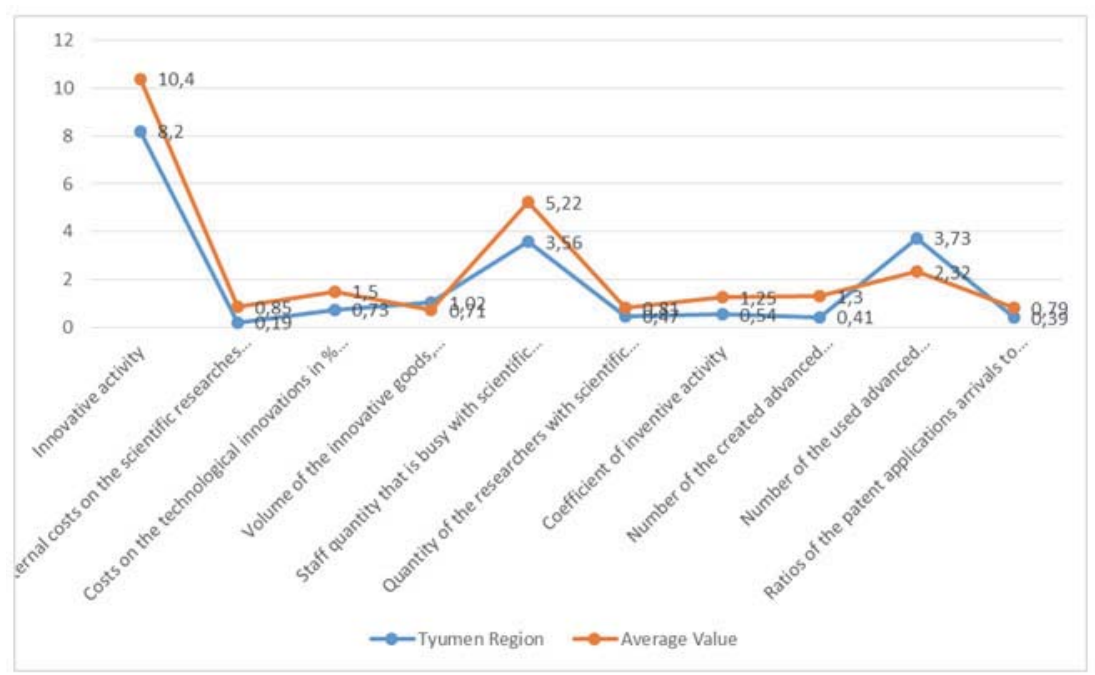

Figure 1. The level of innovative development of the Tyumen region relative the average values of the Russian regions

\section{Concluding Remarks}

The comparison with a region-leader lets us state the low level of innovative regional enterprises and organizations' activity development, besides, the negative dynamics is noted according to the majority of indices, that doesn't correspond to the strategic goals of regional development in the contemporary period.

The analysis of the Tyumen Region innovative system effectiveness lets us reveal two tendencies. Firstly, the region is leading with GRP per capita indices that is connected with a raw index of the regional economy and a high share of fuel-and-energy companies in the structure of industrial production. Moreover, the high index of labour productivity at a high-technology sector is observed. That testifies the substantial potential in the region innovative development. Secondly, the low innovative activity in the region is observed. That prevents the realization of a present potential.

At this situation it is necessary to take a complex of measures in a stimulation of the development of the Tyumen region' circumpolar area that can act as "a locomotive" of the innovative region's development.

The development of hydrocarbon deposits in the Arctic zone actualizes the problem of building an innovative model of the Tyumen region' circumpolar area development, which, in the first place, would have the essential characteristics of the innovative economy, would gave an incentive to the development of new and advanced technologies, in the second place, would promote an effective integration of the oil and gas sector and its transformation into a high-tech and knowledge-intensive sector. The particular relevance is the need to work out directions of the Arctic zone innovative development, allowing to maximize the economic benefits of its development at the national level (by the implementation of inter-regional cooperation), and at the level of the region (by localization).

Scientific interest in the elaboration of innovative development directions of the Tyumen region's Arctic zone is based on the fact that the Arctic zone is seen as a geoeconomic strategic territory of different groups of participants' interests - of the state and regional government, of the oil companies and other business entities, of the public. This circumstance requires finding ways to harmonize existing differences in the strategic interests of different groups of participants.

The emphasis placed on the balanced development of the innovation system subjects and their effective interaction will form the basis for sustainable innovative exploration and development of the Arctic zone. Innovative development north of the Tyumen region must necessarily be associated with the rational use of mineral resources, biodiversity, maintain the ecological balance and, finally, the quality of such difficult climatic conditions.

In this context, we are talking about the formation of an innovative system that satisfies the principles of anthropocentrism and biospherecentrism, where the emphasis is made on achieving the coherence of scientific and technological development and exploitation of natural resources, to ensure an effective balance of national and regional interests and complementary of industrial and innovative development.

Thus, the system economics must act as theoretical and methodological basis of the research. The system economics is a synthetic economic theory that accumulates neoclassical, institutional and evolutionary economics' 
achievements. Using a systematic approach requires consideration and analysis of the economic, social, cultural, technological and environmental determinants of the Tyumen region's circumpolar area innovative development, which will ensure the implementation of the comprehensiveness principle.

The study must be focused on the formation of the scientific and practical vision of the Tyumen region's Arctic zone innovative development based on conceptual issues deep study, a comprehensive study of international experience in the development of the Arctic territories and definition the implement of innovative, social-oriented development of the Tyumen region's circumpolar area. Carrying out the applied research of development the region's circumpolar area innovative model will allow to concretize the content of proposed innovation policy of the Arctic deposits development and to prepare practical recommendations for its implementation. The study can serve as a methodological basis for the working out of a complex target program for the Russian Arctic zone development.

\section{Acknowledgement}

This paper is based on research carried out with the financial support of the grant of the Russian Scientific Foundation (project №14-38-00009).

\section{References}

Barinova, V.A., Maltsev, A.A., Sorokin, A.V. and Eremin, V.A. (2014). Approaches to evaluating the efficiency of the innovation infrastructure facilities in Russia. Innovations, 185 (3)

Dezhina I.G., Saltykov B.G. Formation of the Russian national innovative system and small business' development // Problems of Forecasting. - 2005. - №. 2. - P. 118-128.

Didenko, N., and Skripnuk, D. (2014). The impact of energy resources on social development in Russia. WIT Transactions on Ecology and the Environment, (190), WIT Press.

Eder, L., Filimonov, I., Provornaya, I., and Nemov, V. The main problems of the oil and gas industry's innovative development in the field of oil and gas. Drilling and Oil, (4).

Goxberg L., Kuznetsova I. Innovations as a factor of economic modernization. Structural changes in the Russian industry. Moscow: Publishing House HSE, 2004.

Goxberg L.M. et al. Rate of innovative development of the Russian Federation: an analytical report. The standard of living of the population of regions of Russia. 2012. N.12. P. 120-128

Hochberg, L.M. (2014). Rating of innovative development of the Russian Federation. Issue 2. Moscow: National research university Higher school of economics, $88 \mathrm{p}$.

Ivanova, O., and Sorokina, A. (2013). Rating of Russian innovative regions for the purpose of monitoring and management: version 2013-2.0 < http://www.i-regions.org/projects/regions-development/11192/ (accessed November 10, 2014).

Krugman, P.R. (1993). First Nature, Second Nature, and Metropolitan Location. Journal of Regional Science, (33), 129-144.

Kryukov, V.A. (2009). Oil and gas sector: institutional system requires a "reset". Moscow: Energy, 91 p.

Kuznetsov S.A., Kravchenko N.A., Markov V.D., Yusupova A.T. Innovative Management. Novosibirsk: Publishing House of SB RAS, 2005. $276 \mathrm{p}$.

Pogodaeva, T.V., Rudenko, D.Y., and Simonova, L.M. (2014). Mesoeconomics of Development of the Oil and Gas Extraction Region. Mediterranean Journal of Social Sciences, 4 (13), 49-53. Doi:10.5901/mjss.2014.v5n13p49

Rosstat (2014). Social and Economic Indicators for Russia's Regions 2013. < http://www.gks.ru/bgd/reg//b13_14p/Main.htm> (accessed November 10, 2014).

Yasin E.G., Akendinova N.V., Yakobson L.I., Yakovlev A.E. (2013). Will there be a new model of economic growth in Russia? National Research University "Higher School of Economics". Publishing House HSE. 67 pp.

Zubarevich, N.V. (2011). Regions and Cities of Russia: Scripts 2020. Pro et Contra, (4) 